\title{
ARTICLES
}

\section{SCARLET-LETTER POLITICS: THE RHETORIC OF SHAME IN THE CAMPAIGN TO UNSEAT PRESIDENT BARACK HUSSEIN OBAMA}

\author{
Myra Mendible \\ Florida Gulf Coast University
}

In his March 2008 speech on race in America, President Obama alluded to the "memories of humiliation" that haunt an older generation of blacks in America. His words invoked a time when routine acts of racial shaming served to keep African American men and women "in their place." Publicly shamed bodies serve as emblems of what a society rejects; the stigmatization of black bodies was instrumental in maintaining the nation's racially segregated social order and shaping its political culture. Through shaming practices bodies are criminalized, demonized, cast out or differentiated. In terms of racial history, President Obama's speech locates this tactic safely in America's past. Yet both the 2008 and 2012 presidential campaigns suggest that public shaming remains a politically expedient way to inscribe boundaries of race, ethnicity and other social categories.

This essay considers the politics of shaming deployed during the 2012 Obama-Romney presidential race and during Obama's tenure. I argue that the nation's first black president has been the object of a shaming campaign specifically targeting the "black" body and the "foreign" body as potential threats to the "American" body politic. Examining news media and Internet sources, I show how racially-charged shaming rhetoric and imagery exploit long-standing social anxieties and stereotypes. I focus on public shaming gestures and inducements that function as political tactics intended to enforce hierarchies and boundaries between "white America" and its others.

Forging a more united and inclusive society was one of Barack Obama's defining themes during his first presidential campaign. Following his successful run, pundits and academics alike heralded the advent of a "post-racial" American society. Many claimed that the election of the nation's first African American president showed that race and other embodied social categories no longer played a significant role in America's electoral processes. Any mention of lingering systemic inequalities or racial hostilities could now be discounted by the fact that the 
son of an American white woman and a Kenyon Muslim had been elected president of the United States. But despite President Obama's own attempts to "transcend" race and broaden his constituency, his first term and subsequent campaign for re-election suggest that many Americans regard the nation's changing demographics and the increasing influence of diverse social groups with ambivalence, suspicion, or outright enmity.

Obama's first term exposed certain fault lines in American society, evoking deep-seated apprehensions about race, immigration, and America's status in a post-9/11 world and fueling a reactionary backlash. Throughout his first term in office, Obama faced grinding opposition, divisiveness, and hostility from "Tea Party" Republicans specifically and the GOP generally - so much so that an analysis by The Washington Times showed that in 2011 Congress set a "legislative futility record": they accomplished less than in any other year in history (Dinan, 2012, para. 2). Republican opposition to Obama has been categorical: in a 2011 Gallup poll Obama earned a 12 percent approval rating among Republicans, versus 80 percent among Democrats, making his third year in office the most polarizing on record (Jones, 2012, para. 1). This deep divide —or what political scientists call "asymmetric polarization"- cannot be explained fully by pointing to ideological differences. The results of a recent study by political scientist Keith Poole, which estimated congress and the president's ideological positions by tabulating their "votes" on legislation, suggest that President Obama may be, as a Washington Post headline put it, "the most polarizing moderate ever" (Cillizza and Blake, 2012, emphasis added). Contrary to the popular perception (shaped no doubt by repeated references to Obama as "radical" or "extremist"), Poole's study found that President Obama is more ideologically moderate than any Democratic president since the end of World War II ("An Update on the Presidential Square Wave," 2013).

The deeply polarized state of the union today is a far cry from the one Obama envisioned during his 2004 Democratic Convention speech when he said, "There is not a Black America and a White America and Latino America and Asian America-there's the United States of America." Despite the promise implicit in his election and subsequent reelection, the gridlock and disrespect that greeted his presidency and continue during his second term provokes questions about what identity categories are legitimized, included, or disavowed in the discursive construction of a post-Obama American culture. It also calls attention to the lingering impact of race on political attitudes. Critics publicly denounce Obama with a ferocity usually reserved for foreign enemies or tyrants, high level officials often stoking the fires and leading the charge. These public displays have implications for minorities, whose lives are 
directly impacted by any reactionary backlash. For example, in a 2012 AP survey 51 percent of Americans expressed explicit anti-black attitudes compared with 48 percent in 2008. Similarly, while 52 percent of non-Hispanic whites expressed anti-Hispanic attitudes in a 2011 AP survey that rose to 57 percent in a more recent study (Ross and Agiesta, 2012). Sonya Ross and Jennifer Agiesta (2012) report that more than half of respondents associated words such as "violent" and "lazy" with African Americans and Latinos. As a result, "many African-Americans have talked openly about perceived antagonism toward them since Obama took office. As evidence, they point to events involving police brutality or cite bumper stickers, cartoons and protest posters that mock the president as a lion or a monkey, or lynch him in effigy" (para. 10). These tactics can help shape public opinion and thus public policy: support for affirmative action or other social programs, for example, fluctuates in accordance with prevailing attitudes towards minority populations (Savani, et al, 2011). Racialized shaming displays intentionally exploit the tension produced by competing impulses in American society, particularly between individualism and community, between a politics of assimilation and one of differentiation. As Caroline Howarth (2006) explains, "Stigmatizing representations, as all representations, are more than ways of seeing or cognitive maps: they filter into, and so construct, the institutionalized practices of differentiation, division and discrimination" (p. 45).

Shaming tactics often "brand" Obama by culling familiar caricatures of African-American men such as the "coon" "Sambo" or "Uncle Tom" to imply that Obama lacks the dignity or status necessary to warrant respect or represent America on the world stage. When President Obama attended the G-20 summit in London, controversy ensued over Obama's supposed bow before Saudi King Abdullah. A Washington Times editorial called it a "shocking display of fealty to a foreign potentate" and a "servile gesture" that ran contrary to American tradition ("Editorial" 2009). One cartoon combined two affronts: the President bows to a foreign leader but also seems to "moon" Uncle Sam-thus suggesting not only his indignity but also his arrogance and disdain for America (Figure \#1). Another links this subservience theme with the notion that Obama "apologizes" for America (Figure \#2). In 2010, another caricature making the rounds online recycled the Obama-as-subservient theme: it depicts the president as a shoe shine boy polishing Sarah Palin's shoes. ${ }^{1}$ Issues of "Tea Party Comix," which were circulated and sold online by its creator, Tom Kalb, featured a series of Obama-as-coon car-

1 For a look at several "coon" images, their racist roots, and their revival during Obama's presidency, see <http://www.authentichistory.com/diversity/african/3-coon/5chickwatermelon/index.html> 
icatures (McMorris-Santoro, 2010). As Lawrence Bobo (2011) points out, "the cultural production of demeaning antiblack images-post-cards featuring watermelons on the White House lawn. . .Obama featured in loincloth and with a bone through his nose in ads denouncing the health care bill, a cartoon showing police officers shooting an out-of-control chimpanzee under the heading 'They'll have to find someone else to write the next stimulus bill' [Figure \#3] - are ugly reminders of some of the more overtly racialized reactions to the ascendancy of an African American to the presidency of the United States" (p. 32).



FiguRE \# 2

I enjoy the butt-kissing and the money, but I will need you to apologize a few more times.

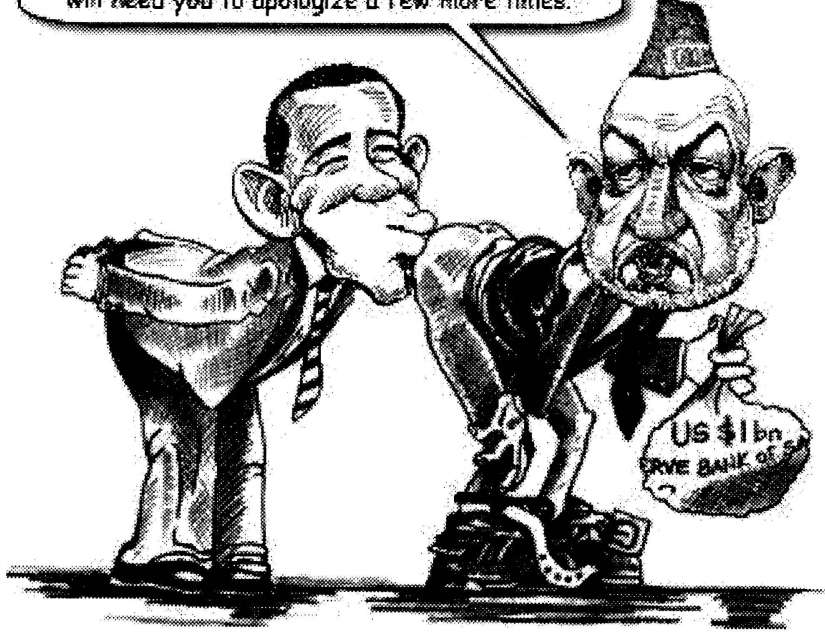


FIGURE \#3

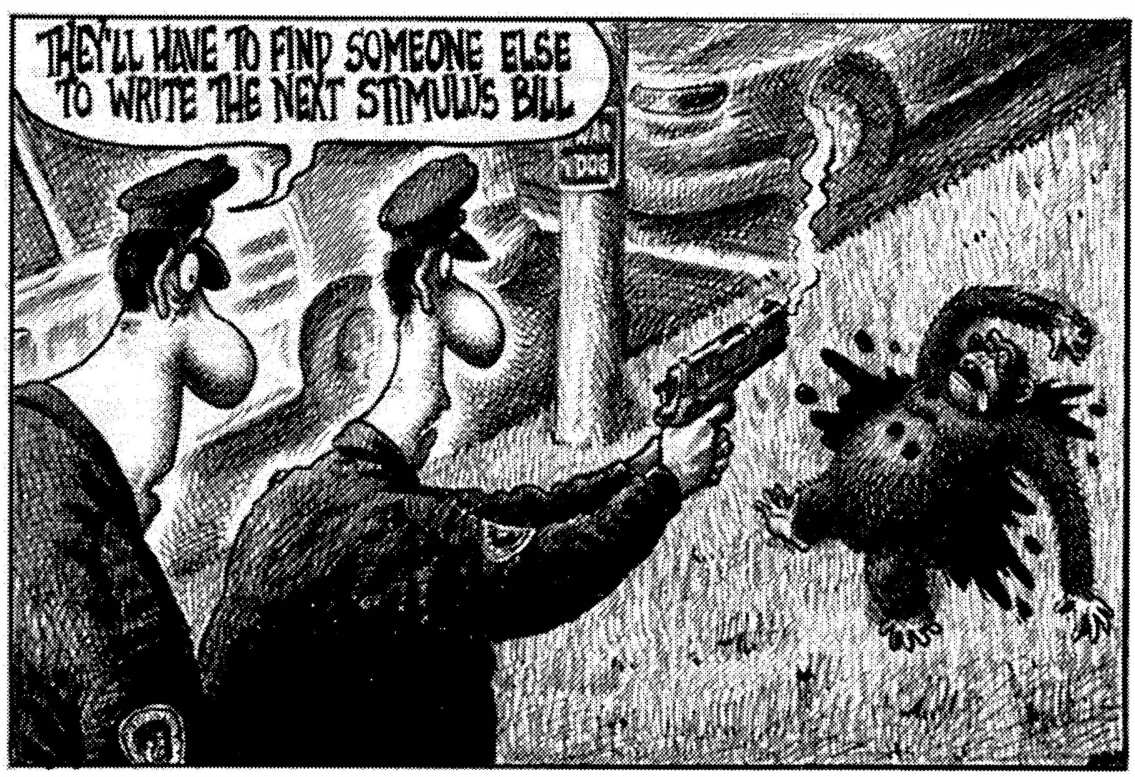

Other images brand Obama as a threat by associating him with negative stereotypes of black men, linking the president to images of the black "gangsta" or thug. One goes so far as to imagine Obama as black rapist; it shows a nude Lady Liberty sitting on the edge of a bed weeping as a smiling Obama says, "Oh stop your whining. You gave all the consent I'll ever need November 2008" (Figure \#4). When asked about her cartoon, conservative blogger Darleen Click denied any racist intent: "This is supposed to be a post-racial era. Then deal with the fact that the President of the United States is the head of a gang that just raped our American principles."2 Clearly, there are still blatantly racist images and claims circulating widely even in this presumably more "enlightened" post-Obama era. As Kay Whitlock (2012) points out, "Criminalizing narratives about President Obama reflect not only a politic of contempt, denunciation, and fear-mongering. They also strike - and are intended to strike - a deep, often unconscious, repository of racist hostility in many people; a virulent (though of ten unacknowledged) racism that is necessary to the further institutionalization of inequality" (para. 8).

2 The image has since been removed from the site, along with the blogger's comments. For a discussion of this event and the broader criminalizing narrative applied against Obama see Kay Whitlock's article, "Criminalizing President Obama." This essay includes links to various images and their historical correlates. <http://criticalmassprogress.com/2012/02/15/cicriminalizing-president-obama/> 


\section{FIGURE \#4}

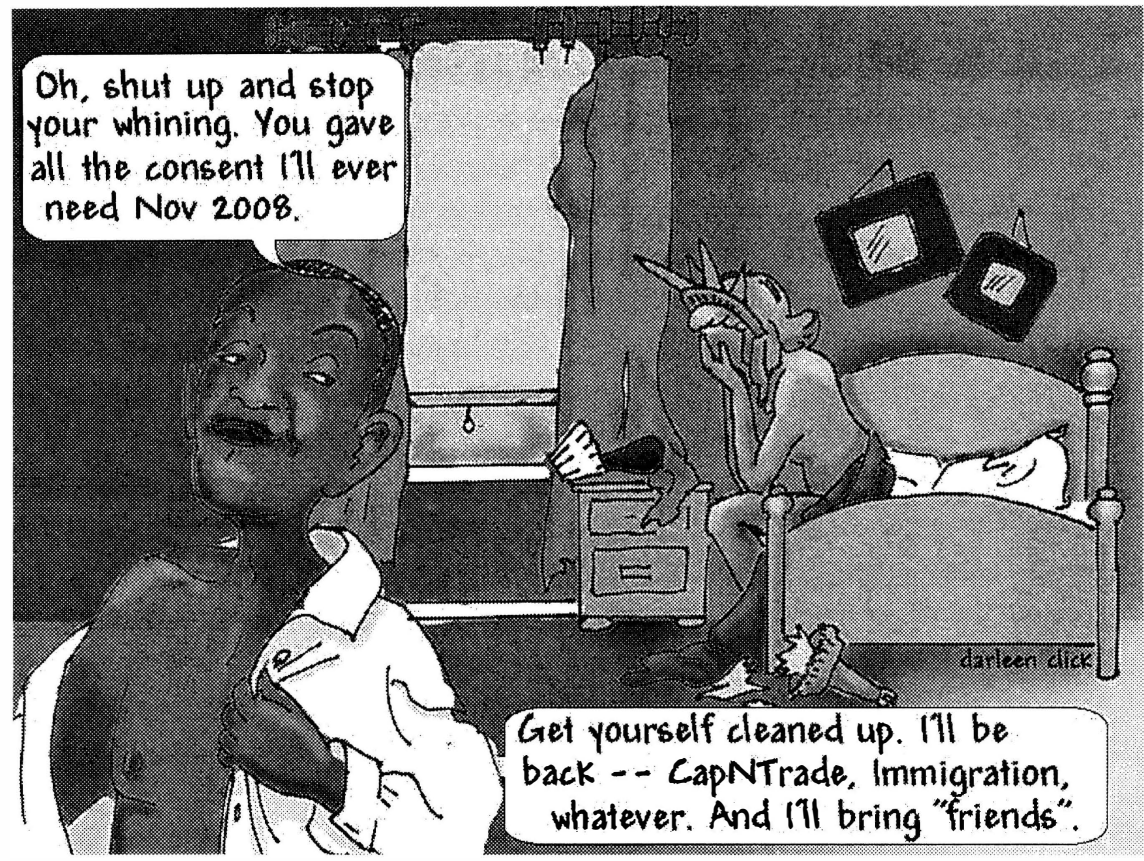

Shaming gestures such as these draw on judgments and strictures that a group shares, core rules and expectations which if broken merit social or moral condemnation. Invoking shared values, the group re-enforces its boundaries and internal coherence. As a form of differentiation and disapproval, collective shaming acts help maintain social and moral hierarchies. They structure and regulate group behaviors, constituting and enforcing social identities such as gender, sexuality, race, ethnicity, religion. David Leverenz argues in Honor Bound: Race and Shame in America (2012) that racial shaming in particular "affirms the coherence of a dominant racial group" (p. 8). "For over three hundred years," Leverenz writes, "shaming after shaming firmed up the pretense that dichotomized skin colors justified white control" (p. 24). He notes that racial shaming tactics typically aim "to reconsolidate white power rather than to make black targets feel ashamed" (p. 9). This is likely because there is no "corrective" or "redemptive" response possible on the part of the target of race-based shaming. If as Leverenz contends racial shaming sees "black" as more basic than "person" (p. 9), the intent is not to "improve" or "reform" the raced other (for how does one "redeem" skin color?) but to empower the shamer. In Leverenz's view, the "more anxious white people are about their status, the more they need to flaunt their superiority" (p. 25). 
The dread of miscegenation or of waning "white power" has a long history in America and is readily tapped for political effect. From Lothrop Stoddard's The Rising Tide of Color Against White WorldSupremacy, published in 1920, to Pat Buchanan's 2001 book, The Death of the West, to the 2009 Atlantic Magazine headline proclaiming the "end of white America," the notion that white U.S.-born citizens are an "oppressed majority" (in Rush Limbaugh's words) increasingly fuels paranoia. The perceived or actual erosion of white privilege earns considerable media attention and invokes elegiac rants from conservative pundits. Obama's presidency, combined with the psychological and economic effects of the great recession, add further weight to the belief that whites-particularly white men-are under attack. As David Leonard (2012) notes in an Ebony opinion piece, white nationalists seized upon President Obama's re-election to increase their ranks: "At Stormfront.org, the hub for global racism, readers were met with a new introduction to the website: 'The recent Obama victory and the resultant antiObama backlash has caused a lot of Whites to visit Stormfront (readership surged up to 600\% more than normal). Welcome." (para. 6-7). Sociologist Charles Gallagher (2011) explains that, "We [whites] went from being a privileged group to all of a sudden becoming. . the new victims. ...You have this perception out there that whites are no longer in control or the majority" (Blake, para. 5-6). In this context, acts of public shaming and humiliation can help assuage bruised egos and reaffirm the group's higher status and worth. Through shaming gestures, an anxious hierarchy may "restore psychological comfort for the group" (Adshead, 2010, p. 206).

\section{American (White) Pride and Racial Shaming in the Age of Obамa}

Most Americans do not identify with the more overt racism expressed by white supremacist organizations or post-election Twitters. ${ }^{3}$ Thus the contemporary politics of shaming often requires a more delicate balance: it must stoke latent racial anxiety and "white pride" discourses while not challenging our positive national self-image as a tolerant $E$ Pluribus Unum democracy. Thus racial shaming strategies of ten involve coding and deflection. Going beyond a longstanding duologue of white

3 Following the 2012 election, the " $n$ " word and "monkey" were trending high on Twitter, with outraged and angry posts denouncing President Obama and his black and Latino supporters. For a sampling of these posts, see J. Lemieux, Ebony (November 8, 2012). Online http://www.ebony.com/news-views/obama-wins-ngger-trends-100\#axzz2M7Z5cE2F. For the results of a data-mapping survey of these posts, see "Mapping racist Tweets in response to President Obama's re-election," The Guardian, Nov. 12, 2012. Online http:// www.guardian.co.uk/news/datablog/2012/nov/09/mapping-racist-tweets-president-obamareelection 
and black, this tactic deploys "patriotic" themes historically aligned with Anglo-American cultural myths and values. These appeals express nostalgia for "traditional American values" and for a time when America ruled the world proudly and "without apology." It invokes an imagined community united by religious (Judeo-Christian) and economic (capitalist/free market) kinship and energized by a so-called "Protestant work ethic." Shaming Obama here depends on excluding him from these foundational narratives - portraying him as an outsider who holds no authentic ties to "American" history or values. He is, as Mitt Romney charged during the campaign, someone who "doesn't believe in American exceptionalism" (“Obama Rebuts Charge," 2012).

During both presidential campaigns, Obama's racial difference was often recoded to signify an indeterminate otherness, a threatening "unAmericanness" that calls into question his legal and cultural right to be president of the United States. In this way, shame is attached to the president by imbuing him with the taint of the foreign and arousing suspicions about his "true" identity or intent. In March of 2010, Republican National Committee fundraising plans made this strategy explicit, calling for an aggressive campaign capitalizing on "fear" of President Obama and socialism. These negative associations evoke a potentially threatening Otherness that invites public condemnation. Thus during the 2012 campaign, Romney campaign co-chair and former New Hampshire Gov. John Sununu explained to Fox News that Obama doesn't understand how the "American system functions" because "he spent his early years in Hawaii smoking something, spent the next set of years in Indonesia" (Volsky, 2012, para. 2). During a conference call the same day, Sununu remarked that he wished that "this president would learn how to be an American." After President Obama's lackluster performance in the first presidential debate, Sununu said of the Harvard-educated Obama, "When you're not that bright you can't get better prepared." Later on an MSNBC, Sununu claimed that the debate had revealed Obama's "incompetence" and referred to the president of the United States as "lazy" (Rothman, 2012).

No one is a member of an exclusive collectivity, and people who are subordinated along one axis of social division may well be dominant along another. But "red letter politics" require reductive categories and associations to clearly differentiate and "brand" the target group. References to welfare or food stamp recipients are often used as code-words for blacks or Latinos, reducing the multiplicity of these identities to fit neatly into a rigid caste system. Once poverty is raced, it is stigmatized, turned into a sign of some moral or character failing inherent in the target group. Black poverty and unemployment rates, extirpated from their complex historical roots, are thus attributable to "their" essential lazi- 
ness, criminality, or willingness to "scam" the system. After all, to confront capitalism's failings is to turn the gaze inward: to invite a sense of collective responsibility and perhaps even stir up the embers of shame. One group "saves face" through a gesture of deferral and disavowal while the other becomes the public face of need, dependency, and lack.

So it is that during both presidential campaigns Obama's opponents made it a point to distinguish "hard working Americans" (read: whites) from those who lack the "Protestant work ethic" identified with WASP culture in America. Ronald Reagan had famously chided "welfare queens" during his presidency, and Hillary Clinton revived these associations when she ran against Obama: "I have a much broader base to build a winning coalition on," she told a USA Today reporter. Clinton then cited Sen. Obama's weak "support among working, hard-working Americans, white Americans" (Kiely and Lawrence, 2008). When Representative Joe Wilson from South Carolina shouted "You lie!" at President Obama during his 2009 healthcare address before Congress, he was reacting to the false notion that Obama aimed to provide illegal immigrants with government healthcare subsidies. Leverenz (2012) aptly notes that in "antebellum South Carolina, Wilson's accusation would have provoked a duel, since it was a flagrant shaming" (p. 173). But for those who defended Wilson's disrespectful outburst, the issue seemed to boil down to the same equation: Obama was going to force "us" to provide handouts for "them" (losers, moochers, and illegals).

In his 2008 speech on race, "A More Perfect Union," Obama pointed to the "lack of economic opportunity among black men, and the shame and frustration that came from not being able to provide for one's family" (Obama, 2008, para. 32). Throughout his presidency, however, he has been criticized for not directly addressing black unemployment rates-almost twice that of whites. Maintaining a "post-race" stance, Obama has responded to critics by saying that "it's a mistake to start thinking in terms of particular ethnic segments of the United States rather than to think that we are all in this together and we are all going to get out of this together" (Jackson, 2009). The President's attempts to propose "color blind" economic policies during the great recession have not stopped opponents from culling the myth of black entitlement. Here scarlet-letter politics associate blacks and minorities with Romney's 47 percent "who are dependent upon government, who believe that they are victims, who believe the government has a responsibility to care for them, who believe that they are entitled to health care, to food, to housing, to you-name-it" (Corn, 2012, para. 2). One Romney campaign ad falsely accused Obama of gutting welfare reforms, claiming that "Under Obama's plan, you wouldn't have to work. . .. They just send you a welfare check" (Edsall, 2012). After Obama's re-election, Romney told 
donors that Obama had been re-elected because of the "gifts" that he offered African American and Latino voters (Daniel, 2012).

During the 2012 presidential campaign, Newt Gingrich echoed his 1994 Contract with America, which targeted federal food stamp entitlement programs for elimination. At a Fox News-Wall Street Journal sponsored debate in Myrtle Beach, South Carolina, he referred to President Obama as "the best food stamp president in history," culling associations between the black president and entitlement programs. Relying on racist stereotypes that attribute blacks' economic status to laziness or lack of willpower, Gingrich asserted the difference between "them" (Obama and the 95 percent of blacks who supported him in the first election) and "us" (a majority white Republican audience, and by extension, "real" i.e. "hard working" Americans): "We believe in work. We believe people should learn to work and that we're opposed to dependency" (2012, Green, para. 1). Despite the fact that most recipients of federal food aid are children, elderly, and severely disabled persons and that only 22 percent of all food stamp recipients are black, Gingrich was able to exploit assumptions and familiar stereotypes for effect-eliciting a standing ovation in the process.

Criticism of the President often involves an amorphous "Othering" process: references to Obama's "questionable" birth certificate raise doubts about whether he was "really" born in America; allusions to his "Kenyon father" the "Luo tribesman" arouse suspicions about Obama's "Africanness"; use of the word "socialist" in conjunction with any policy Obama proposes, regardless of how "centrist" or moderate or capitalist, spooks middle-class Americans into opposing what might benefit them economically; and opportune uttering of his middle name, Hussein, works to denote Muslim or Middle Eastern affiliations with all that entails in post-9/11 America. Thus distortion and misinformation persist, circulated via popular conservative media outlets, talk radio, internet blogs, and even prominent political leaders. Not surprisingly, a Harris poll conducted in March of 2010 showed that 67 percent of Republicans (and 77 percent of Tea Party supporters) believe Obama is a socialist, another 45 percent that he is the "domestic enemy that the Constitution speaks of" and 45 percent that he was not born in the United States and is therefore ineligible for the presidency (For example, Figure \#5 assumes that Obama was born in a village in Kenya). Twenty-four percent surveyed believe he may be the Anti-Christ (Taylor, 2010). In a television interview on July 23, 2009, Watergate conspirator Gordon Liddy suggested that Obama might be "an illegal alien" (Stelter, para. 14). Such notions persisted throughout Obama's first term and buttressed legal rationales for "policing" people of color. As Melissa Harris-Perry notes, "As the president was being asked to show his papers to the nation, state 
governments in Arizona, Alabama and South Carolina empowered police officers, school officials and merchants to demand proof of citizenship from anyone they deemed suspicious of immigration violations-suspicions that are triggered primarily by racial, ethnic and linguistic profiling" (para. 6).

FIGURE \#5

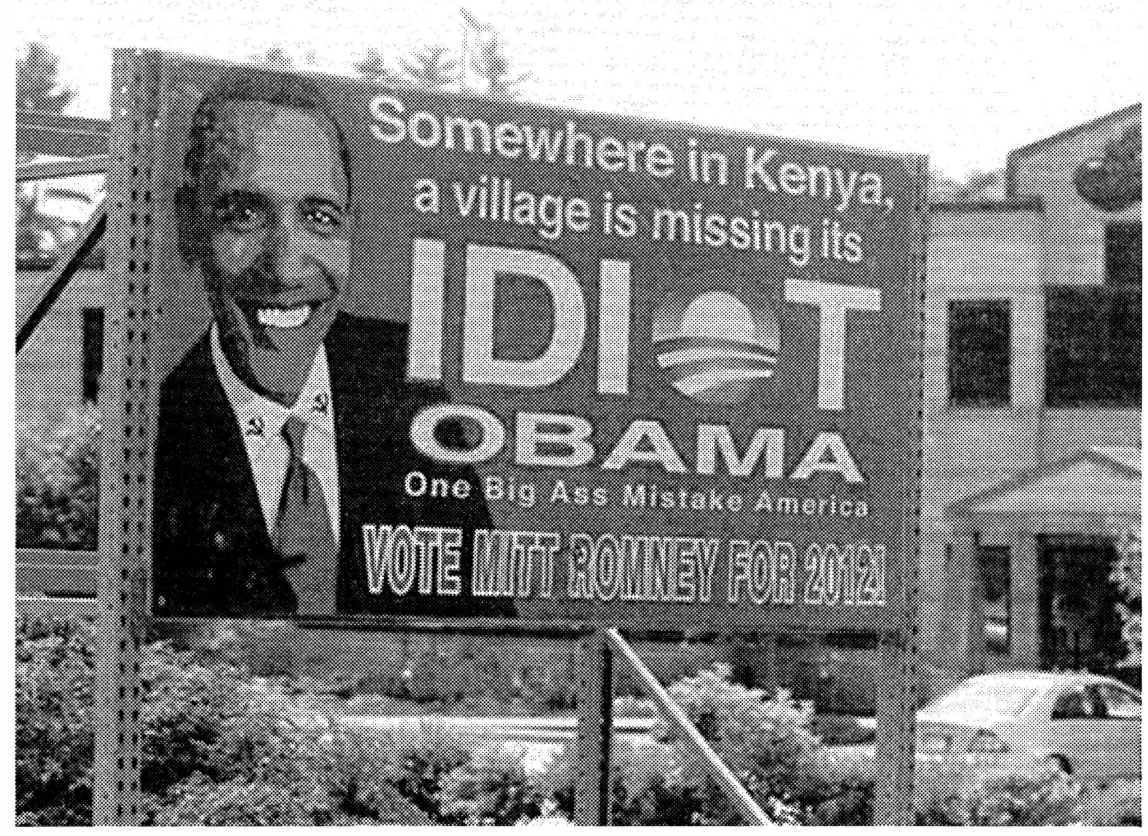

This need to position Obama as somehow "outside" the parameters of what is legitimately "American" was first on display during the 2008 presidential campaign, though during that contest Senator John McCain corrected an audience member who referred to Obama as a Muslim. Yet during the 2012 campaign stop in Florida, GOP presidential hopeful Rick Santorum smiled and nodded as a woman in the audience told him, "I never refer to Obama as President Obama because legally he is not [president]. ... He is an avowed Muslim and my question is, why isn't something being done to get him out of government? He has no legal right to be calling himself president" (Aigner-Treworgy, 2012, para. 2). When questioned about his silence in the face of this factually inaccurate claim, Santorum responded, "I don't feel it's my obligation every time someone says something I don't agree with to contradict them." Further fueling fears of Obama's otherness, Santorum told audiences at Columbus, Ohio campaign stop: Obama's agenda is "not about you. It's not about your 
quality of life. It's not about your jobs. It's about. . ..Some phony theology. . .. not a theology based on the Bible" (Walshe, 2012, para. 2-3).

Obama was born in Hawaii in 1961 and did not even visit Kenya until 1987, but this has not stopped some prominent conservatives from attributing his "difference" to his Kenyon ancestry. James Mann (2010) coined the phrase the "Kenya paranoia" in reference to this phenomenon. But Mann is "not talking here about simply the ideas of Republicans, the right wing or the political fringes. Rather, the Kenya paranoia has been showing up in the politest society, among journalists and even high-ranking diplomats." Mann argues that this "paranoia" about Obama's "difference" is not even restricted to Americans: a British television reporter wanted to interview Mann about Obama's views of the world because, " 'He has different roots than all other presidents,' the reporter said. 'He doesn't have ties to Europe" (para. 6). Mann points to the irony of this assumption that Obama is not "European" enough-despite a white mother with British ancestry. Similarly, former Arkansas governor and twice GOP presidential candidate Mike Huckabee attributed Obama's "difference" to his "having grown up in Kenya" (an untruth that forced his political action committee spokesman, Hogan Gidley, to explain that "the governor. . . wasn't talking about the president's place of birth the governor believes the president was born in Hawaii") [Shear, 2011]. We should note the use of the word "believes" rather than "knows," as if Obama's citizenship was simply a matter of belief.

\section{Mammies, Hookers, and Ho's: Michelle's Body and the Politics OF SHAME}

Black women's bodies have historically been subjected to the regulatory power of shame. The stigmatization of black femininity prompts a level of self-discipline and surveillance reflected in Toni Morrison's The Bluest Eye (1970) in a passage describing African-American women's attempts to tame their embodied differences: "They hold their behind in for fear of a sway too free; when they wear lipstick, they never cover the full mouth for fear of lips too thick, and they worry, worry, worry about the edges of their hair" (77-78). Michelle's body reflect white America's love/hate relationship with black female beauty: on the one hand, features often identified with black women (full lips, dark skin, muscular physique) are highly desirable, and white women pay handsomely for everything from lip injections to tanning beds to butt implants. On the other, black women have long borne stigmas associated with primitivism, animalistic, and excessive or aberrant sexuality. These competing tensions inform some of the polarized reactions Michelle's body elicits.

Much is written about Barack Obama's physical prowess-his competitive basketball games, daily workout on the treadmill and with free 
weights. A photo of Barack in bathing shorts at the beach went viral, with bloggers commenting on the president's pectorals and lean physique. As Leola Johnson (2010) remarks, "the light-skinned, hyperfit Obama is frequently sexualized and otherwise physically objectified by his fans. Thus, in the early days of his administration, the most widely circulated magazine and Internet images of Obama, featured in black and white media alike, showed him as a hyperfit sex object; a cool, sunglasswearing business man; or a combination of those things" (p. 247).

Michelle shares her husband's commitment to fitness, reportedly doing an hour a day of cardio, weight training and calisthenics. She has also made childhood obesity a priority, raising awareness of this health issue and leading efforts to improve eating habits. Her stature, impressive biceps, and grace, like Barack's lean body, have been the subject of much fascination and praise. Yet Michelle's body is also objectified as shameful, made to sign in for a range of degrading stereotypes of black women. Her "Let's Move!" campaign, White House vegetable garden and efforts to encourage healthy eating habits have been mocked and caricatured by political opponents. Despite the First Lady's enviable intellectual and physical strength or acclaimed fashion sense, her body has consistently been the subject of degrading comments and racialized shaming images.

One image that considerable Internet chatter was the photo-shopped portrait of the First Lady on the cover of a leading Spanish magazine, Magazine de Fuera de Serie, which featured the image of the First Lady's face on the body of a bare-breasted female slave (Figure \#6). The original painting, Portrait d'une negresse, was completed in 1800 by French artist Marie-Guillemine Benoist as a tribute. The magazine's cover story "Michelle Tataranieta De Esclava, Dueña De América" ("Michelle Great Granddaughter of a Slave, Lady of America") heaped praise on Michelle, and the French/English artist who conceived the piece, Karine Percheron-Daniel, has defended the image, arguing that it acknowledges Michelle's slave ancestry to celebrate her current status and empowerment. But as Althea Legal-Miller (2012) writes in Clutch Magazine, the "portrait robs Obama of her identity, voice, and intellect, and visually shackles her to a politically passive subject, resigned to an assigned role as slave." Legal-Miller concludes that "These images largely determined by stereotypes used to legitimize racial and gender oppression-speak to a painful history of exploitation and erotic objectification, which continues to manifest in multiple contexts across the black female diaspora" (2012, para. 5). I cannot help but wonder if any major magazine would have dared depict a topless Nancy Reagan, Barbara or Laura Bush on their cover. 
FIGURE \#6



More ubiquitous are the Internet jokes and emails that target Michelle's backside. In mainstream United States culture, big butts have historically been associated with "low" status or "vulgar" sexuality. The buttocks are a symbolic site in the body, with female buttocks in particular functioning as metaphors for traits that a society values or rejects. Their meanings vary between cultures and among ethnic groups; while a bounteous butt may elicit disgust or disdain in some social circles, it evokes a range of positive associations in others. A woman's failure to reign in an unruly butt connoted her lack of discipline and self-control, and by association, her inferior moral character. Western societies long associated a big butt with "unnatural" sex, excrement, or the excess and physicality identified with non-Western women. Let us not forget that colonized nineteenth century rump belonging to Saartje Baartman, dubbed by her masters and impresarios the "Hottentot Venus." This young African woman's protruding butt served as a sign of all that perplexed, fascinated, and horrified Europeans in the early 1800s about their darker others. Displayed throughout Europe, Saartje's sign value as deviant "other" body persisted even after her death at twenty-five. Doctors dissected and preserved her genitals in glass jars, her large buttocks displayed for curious spectators eager to see bodily evidence of the African woman's propensity to excess.

Ideology often masqueraded as biology, and the body of the black woman in particular signed in for a range of moral and physiological "pathologies." As Sander Gilman (1985) has argued, "When the nineteenth century saw the black female, it saw her in terms of her buttocks, and saw represented by the buttocks all the anomalies of her genitalia" (p. 90). This in turn served to justify their subordination, as the "presence 
of exaggerated buttocks" signaled "other, hidden sexual signs, both physical and temperamental, of the black female" (p. 91). By casting the "stigmata of degeneracy" (p. 89) on black female anatomy and sexuality, her "difference" could be read as a sign of her inherent inferiority and "primitive sexual appetite" (p. 85). "Sarah Bartmann's genitalia and buttocks summarized her essence for the nineteenth-century observer, as indeed they continue to do for twentieth-century observers. . ." (p. 88). The Musee de l'homme in Paris would finally return Bartmann's remains to South Africa in 2002.

In recent years women of color have challenged dominant beauty myths and embraced their curves-with rap music and celebrity magazines singing the praises of big booty. Voluptuous female buttocks have become a valuable commodity, exploited in advertising campaigns, music videos, and specialty men's magazines. However, there is a lingering stigma attached to the protruding butt in America's conservative mainstream, where it can still elicit tropes of race and class. In her article, "First Lady Got Back," Erin Aubry Kaplan (2008) notes that a protruding butt has been "both vilified and fetishized as the most singular of all black female features, more unsettling than dark skin and full lips, the thing that marked black women as uncouth and not quite ready for civilization. . " (para. 6). Kaplan celebrates the emergence of Michelle Obama's "solid, round, black, Class A boo-ta" on the nation's political stage, noting that "As America fretted about [Barack] Obama's exoticism and he sought to calm the waters with speeches about unity and common experience.. . .Here was one clear signifier of blackness that couldn't be tamed, muted or otherwise made invisible" (para. 5). To Kaplan and other women who do not see their bodies reflected in the images typically gracing magazine covers, Michelle's butt evokes confidence and even ethnic pride.

But among Obama's opponents, Michelle's butt is a political target-a sign of shameful excess, lack of discipline, or low status. Wisconsin Rep. Jim Sensenbrenner made a comment about the First Lady's "large posterior" while talking to church members at a Christmas bazaar ("US Rep apologizes"). Rush Limbaugh, not exactly a model of physical perfection, has nick-named her "Michelle, My Butt." Like many other conservative pundits, Limbaugh seems compelled to remark on Michelle's butt. Chastising John McCain for "kissing Obama's butt" by crediting him with the death of dictator Muammar Gadhafi, Limbaugh remarked, "Obama doesn't have a butt. Compared to his wife, he really doesn't have a butt" (Krepel \& Rosenberg, 2012, para. 24). Media Matters reported that "one of Andrew Breitbart's websites posted a cartoon of an overweight Michelle Obama eating a plate-full of hamburgers and saying: "Shut up and pass the bacon!" (Krepel \& Rosenberg, 2012, para. 
19). Another popular cartoon imposes the First Lady's face on the body of a woman with exaggerated buttocks. The caption reads, "Muchelle Obama Stars in Boogie Pork Fever."

Following suit, an Alabama High School head coach was caught on tape blaming "fat butt Michelle Obama" for the new low-calorie school lunches (Singleton-Rickman, 2013, para. 3). These "fat butt" jokes and images are not restricted to online cartoons or politicians who claim to have "misspoken." Journalist David Kahane (2011) wrote in a National Review article: "Michelle would have a real shot of slipping into Queen Kapiolani's muumuu collection and making it her own, especially after a few more meals of short ribs in Vail" (para. 5). One email circulating during the 2012 campaign compares the backsides of two European First Ladies, Carla Bruni Sarkozy (former model and wife of former French president Sarkozy) and Spain's Princess Letizia with Michelle's, contrasting their fashion sense and butt size with a photo shopped image of Michelle's backside where she appears as a kind of "mammie" figure beside the sleek European women.

All of these negative associations are at play in an image circulating on the Internet that not only exaggerates Michelle's backside but makes it her defining feature. In this photo shopped image Michelle Obama is reduced to a sign of vulgar excess, her body posed in a way meant to evoke disgust in the viewer. As William Ian Miller argues in The Anatomy of Disgust, the anus "is the essence of lowness, of untouchability" in Western culture (1997, p. 100). More than any other orifice, it has "the lowest-status place on the body, rendered disgusting by feces and buffoonish and comical by gas" (Miller, 1997, p. 100). The body of the First Lady appears poised to commit a shameful transgression that invokes both of these social taboos: defecating and farting in public. This dual affront to social propriety and hygiene strips Michelle of dignity, turning her into a figure that can evoke only contempt, opprobrium, or disdainful laughter. Her imagined shamelessness (depicted through the "mooning" gesture and punctuated by the facial expression) seems intended to taunt the viewer, and by extension, the American citizenry. Another image (Figure \#8) making the rounds via emails and Internet postings during the 2012 campaign turns the First Lady into a streetwalker: in it Michelle Obama is soliciting "clients" on the side of the road, holding her skirt up to expose her genitals to passing cars. The caption reads: "How Michelle and Barack Obama first met." Again, the photo draws on familiar caricatures of black female sexuality as deviant, excessive, or criminal-a contemporary Jezebel in the White House. 


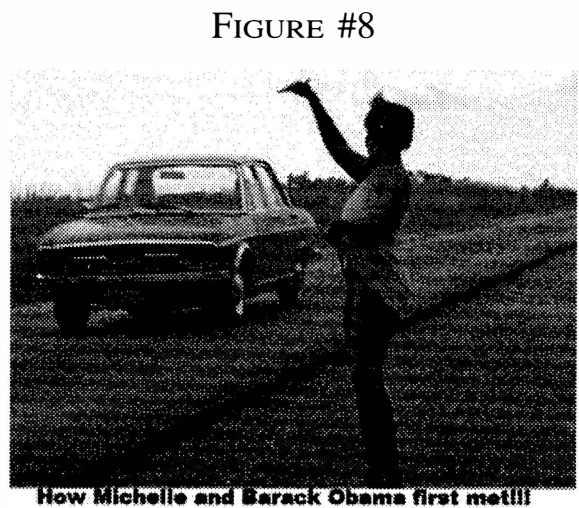

Public shaming tactics have always been part of America's political culture, and caricatures of opponents invariably involve exaggerated physical features. As Charles Press explains in his book, The Political Cartoon, "The cartoon is really an exaggeration to get at an underlying truth, which it conveys through a message, demonstrating a mood around the social or political situation that inspired the cartoon." But while these images always exaggerate traits or features, they rely for their meaning and effect on pre-existing perceptions and assumptions about the individual or group targeted. The shaming tactics I've identified here all draw on familiar racial stereotypes for their effect by culling a history of racial associations that have stigmatized and differentiated African Americans. The political effect of these tactics depends on the extent to which the viewer is "in" on the pun, joke, or trope in play. Thus shaming techniques such as these can also backfire. Many conservatives reject these tactics and refuse to be "in" on the joke, and Americans did give Obama a second term. A January 2013 Public Policy Poll shows that Democrats' approval rating (-12 at 38/50) is a net 48 points better than their Republican counterparts (-60 at 15/75) [Public Policy Polling, Republicans in Congress have only a $25 \%$ approval rating even with the GOP base. Given this reversal of fortune, it may well be that shame is finally coming home to roost.

\section{REFERENCES}

Adshead, G. (2010). Commentary: Till we have faces-On humiliation. Journal of the American Academy of Psychiatry and the Law Online, 38(2), 205-8.

Aigner-Treworgy, A. (2012, Jan. 23). Santorum ignores charge Obama is a Muslim. CNN Retrieved from http://politicalticker.blogs.cnn.com/ 2012/01/23/santorum-ignores-charge-obama-is-a-muslim/ 
An Update on the Presidential Square Wave. (2013, Jan. 18). [Web log post] Retrieved from http://voteview.com/blog/?p=735

Blackwell, K. and Klukowski, K. (2010). The Blueprint: Obama's Plan to Subvert the Constitution and Build an Imperial Presidency. Guilford, Connecticut: Lyons Press.

Blake, J. (2011, March 4). Are whites really oppressed? CNN U.S. Retrieved from http://www.cnn.com/2010/US/12/21/white.persecution /index.html

Bobo, L. (2011). Somewhere between Jim Crow and Post-Racialism: Reflections on the racial divide in America today. Daedalus, 140(2), 11-36.

Cillizza, C. and A. Blake. Obama: The most polarizing moderate ever. (2012, Jan. 30). Retrieved from http://www.washingtonpost.com/ blogs/the-fix/post/obama-the-most-polarizing-president-ever/2012/ 01/29/gIQAmmkBbQ_blog.html

Corn, D. (2012, Sept. 17). Secret Video: Romney tells millionaire donors exactly what he thinks of Obama voters. Mother Jones. Retrieved from http://www.motherjones.com/politics/2012/09/secret-videoromney-private-fundraiser

Daniel, D. K. (2012, Nov. 14). Mitt Romney: Obama won with 'gifts' to blacks, Hispanics, young voters. Huffington Post. Retrieved from http://www.huffingtonpost.com/2012/11/14/mitt-romney-obamagifts_n_2133529.html

Dinan, S. (2012, Jan. 15). Congress logs most unproductive legislative year on record. Washington Times. Retrieved from http://newmedia journal.us/indx.php/item/4216

Editorial: Barack takes a bow. (2009, April 7). Washington Times. Retrieved from http://www.washingtontimes.com/news/2009/apr/7/ barack-takes-a-bow/

Edsall, T. B. (2012, Aug. 27). Making the campaign about race. New York Times. Retrieved from http://campaignstops.blogs.nytimes. com/2012/08/27/making-the-election-about-race/

Gates, H. L. Jr., Editor. (Autumn 1985). Editor's Introduction: Writing "Race" and the difference it makes. Critical Inquiry, 12(1), pp. 120.

Gilbert, P. (1998). What is shame? Some core issues and controversies. In P. Gilbert \& B. Andrews (eds.), Interpersonal Behavior, Psychopathology and Culture. Oxford: Oxford University Press.

Gilman, S. J. (2003). "Black bodies, white bodies." In A. Jones (Ed.), The feminism and visual culture reader (pp.136-150). 
Gilman, S. L. (1985). Difference and pathology: stereotypes of sexuality, race, and madness. Ithaca, NY: Cornell University Press.

Green, J. (2012, Jan. 19). Newt Gingrich's dodgy attack on food stamps. Bloomberg BusinessWeek. Retrieved from http://www.business week.com/politics-policy/joshua-green-on-politics/archives/2012/ 01/newt_gingrichs_dodgy_attack_on_food_stamps.html

Harris-Perry, M. (2012, March 28). Trayvon Martin: What it's like to be a problem. The Nation. Retrieved from http://www.thenation.com/ article/167085/trayvon-martin-what-its-be-problem\#

Howarth, C. (2006). "A social representation is not a quiet thing": Exploring the critical potential of social representations theory. British Journal of Social Psychology, 45, 65 - 86.

Jackson, D. (2009, Dec. 3). Obama rejects congressional black caucus criticism. USA Today. Retrieved from http://content.usatoday.com/ communities/theoval/post/2009/12/obama-rejects-congressionalblack-caucus-criticism-/1\#.URBDEmcb140

Jones, J. Obama Ratings Historically Polarized. (2012, Jan. 27). Retrieved from http://www.gallup.com/poll/152222/obama-ratingshistorically-polarized.aspx

Johnson, L. (2010). Obama's body and the liberal body politic. International Journal of Communication, 4, 246-252.

Kahane, D. (2011, March 15). Obama: The man who would be king. National Review Online. Retrieved from http://www.nationalreview .com/articles/262121/obama-man-who-would-be-king-david-kahane

Kaplan, E. A. (2008, Nov. 18). First Lady got back. USA Today. Retrieved from http://www.salon.com/2008/11/18/michelles_booty/

Kiely, K. and Lawrence, J. (2008, May 8). Clinton makes case for wide appeal. USA Today Retrieved from http://usatoday30.usatoday .com/news/politics/election2008/2008-05-07-clintoninterview_ N.htm

Klein, A, and B. Elliott. (2010). The Manchurian President: Barack Obama's Ties to Communists, Socialists, and Other Anti-American Extremists. New York: World Net Daily Books.

Krepel T. and L. Rosenberg. (2012, Dec. 4). Michelle Obama derangement syndrome: Four years, 40 smears. Media Matters. Retrieved from http://mediamatters.org/research/2012/09/04/michelle-obamaderangement-syndrome-four-years/189737

Legal-Miller, A. (2012, Aug. 27). Michelle Obama undressed: Lost in translation or just racist? Clutch Magazine. Retrieved from http:// 
www.clutchmagonline.com/2012/08/michelle-obama-undressedlost-in-translation-or-just-racist/

Leonard, D. (2012, Nov. 13). Obama and the death of white power. $E b$ ony. Retrieved from http://www.ebony.com/news-views/obama-and -the-death-of-white-power-100\#axzz2M7Z5cE2F

Leverenz, D. (2012). Honor Bound: Race and Shame in America. New Jersey: Rutgers University Press.

Mann, J. (2010, Sept. 28). It's not just D’Souza. British People think Obama is a Kenyon anti-colonialist too. New Republic. Retrieved from http://www.newrepublic.com/blog/foreign-policy/77973/ dinesh-dsouza-british-kenyan-anti-colonial\#

McMorris-Santoro, E. (2010, Aug 2). Creator of racist 'Tea Party Comix' speaks: I do hate Obama, but I'm no racist. TPM Muckraker. Retrieved from http://tpmmuckraker.talkingpointsmemo.com/ 2010/08/tea_party_comix_creator_speaks_theyre_not_racist_t.php

Morrison, T. (1970). The Bluest Eye. New York: Penguin. Obama Rebuts Charge that he doesn't believe in American exceptionalism. (2012, April 2). Huffington Post. Retrieved from http://www.huffington post.com/2012/04/02/obama-american-exceptionalism_n_1397764 .html

Obama, Barack. (2008, March 18). A More Perfect Union: The Race Speech." Philadelphia, PA. Obamaspeeches.com. Retrieved from http://obamaspeeches.com/E05-Barack-Obama-A-More-PerfectUnion-the-Race-Speech-Philadelphia-PA-March-18-2008.htm

Public Policy Polling. (2013, January, 9). Images of NRA, Congressional Republicans on the decline. Retrieved from http://www.publicpolicy polling.com/main/2013/01/images-of-nra-congressional-republicans -on-the-decline.html

Ross, S. and J. Agiesta. (2012, Oct. 27). Racial Views: Poll shows majority harbor prejudice against blacks. Huffington Post. Retrieved from http://www.huffingtonpost.com/2012/10/27/racial-views-new-pollssh_n_2029423.html?icid=Maing-grid7\%7Caim\%7Cdl1\%7Csec3_ lnk1\%26pLid\%3D226553

Rothman, N. (2012, Oct. 4). Andrea Mitchell visibly shocked after Sununu calls Obama "lazy," asks him if he would take it back. Mediaite. Retrieved from http://www.mediaite.com/tv/andreamitchell-visibly-shocked-after-sununu-calls-obama-lazy-asks-himif-he-would-take-it-back/

Savani, K., N. M. Stephens, and H. R. Markus. (2011, June 22). The unanticipated interpersonal and societal consequences of choice: 
Victim blaming and reduced support for the public good. Psychological Science, 22, 795-802.

Shear, M.D. (2011, March 1). Huckabee questions Obama birth certificate. New York Times. The Caucus NYT Blog. Retrieved from http:/ /thecaucus.blogs.nytimes.com/2011/03/01/huckabee-questionsobama-birth-certificate-claims-he-was-raised-in-kenya/

Singleton-Rickman, L. (2013, Jan. 30). Teacher linked to gay slurs at school. TimesDaily.com. Retrieved from http://timesdaily.com/ stories/Teacher-linked-to-gay-slurs-a-chool,201960

Stelter, B. (2009, July 25). A dispute over Obama's birth lives on in the media. New York Times, B2.

Taylor, H. (2010, March 23). "Wingnuts" and President Obama. Harris Poll Interactive. Retrieved from http://www.harrisinteractive.com/ vault/Harris_Interactive_Poll_Politics_Wingnuts_2010_03.pdf

US Rep apologizes to First Lady on "Big Butt" insult. (2011, Dec. 22). KHQ News Online. Retrieved from http://www.khq.com/story/1637 8814/michelle-obamas-backside-under-fire

Volski, I. Romney Campaign: Obama Can't Create Jobs "Because He Spent His Early Years In Hawaii Smoking Something." (2012, July 17). Think Progress. Retrieved from http://thinkprogress.org/politics /2012/07/17/531231/romney-campaign-obama-cant-create-jobs-be cause-he-spent-his-early-years-in-hawaii-smoking-something/

Walshe, S. (2012, Feb. 18). Santorum says 'President's agenda' is based on a 'phony theology.' ABC News. Retrieved from http://abcnews. go.com/blogs/politics/2012/02/santorum-says-presidents-agenda-isbased-on-a-phony-theology/

Whitlock, K. (2012, Feb. 17). Criminalizing President Obama. [Web log post]. Retrieved from http://www.thepeoplesview.net/2012/02/cicriminalizing-president-obama.html 